Illinois State University

ISU ReD: Research and eData

Theses and Dissertations

7-27-2018

\title{
Gender-Exclusive Language: Women's Perception Of Linguistic Ostracism, Voice, And Power In Politics
}

Michelle Roxanne Grzybowski

Illinois State University, MichelleGrzybowski@gmail.com

Follow this and additional works at: https://ir.library.illinoisstate.edu/etd

Part of the Feminist, Gender, and Sexuality Studies Commons, Other Languages, Societies, and Cultures Commons, and the Political Science Commons

\section{Recommended Citation}

Grzybowski, Michelle Roxanne, "Gender-Exclusive Language: Women's Perception Of Linguistic Ostracism, Voice, And Power In Politics" (2018). Theses and Dissertations. 1045.

https://ir.library.illinoisstate.edu/etd/1045

This Thesis is brought to you for free and open access by ISU ReD: Research and eData. It has been accepted for inclusion in Theses and Dissertations by an authorized administrator of ISU ReD: Research and eData. For more information, please contact ISUReD@ilstu.edu. 


\section{GENDER-EXCLUSIVE LANGUAGE: WOMEN'S PERCEPTION \\ OF LINGUISTIC OSTRACISM, VOICE, AND \\ POWER IN POLITICS}

Michelle Roxanne Grzybowski

48 Pages

Gender-exclusive language is a type of subtly sexist language that makes reference to a single gender group thereby excluding other gender groups (Stout \& Dasgupta, 2011). Two studies examined how the use of gender-exclusive language impacts the experiences of women who were elected members of county boards. Specifically, the studies surveyed county board members in the states of Illinois and Wisconsin to determine whether the naturally occurring variation between the use of gender-exclusive language (e.g., using chairman to indicate both men and women) or gender-neutral language (e.g., chair or chairperson) was related to perceptions of ostracism and a sense of empowerment among female board members.

Results indicated a relationship between the masculine generic linguistic biases (e.g., using chairman to refer to the presiding officers instead of chair or chairperson) and the overall representation of general women members as well as women leadership representation on county boards (i.e., boards using gender-exclusive language had fewer women general members as well as women leaders). Additional analyses revealed that women who served on county boards that used gender-exclusive language in referring to their presiding officers reported having less power and feeling that their voices were not being heard in comparison to women who served on boards 
using gender-neutral language; these perceptions were in turn related to women's feeling ostracized. Those who felt less power and less voice felt more ostracized. KEYWORDS: Gender, Language, Ostracism, Politics 


\title{
GENDER-EXCLUSIVE LANGUAGE: WOMEN'S PERCEPTION \\ OF LINGUISTIC OSTRACISM, VOICE, AND \\ POWER IN POLITICS
}

MICHELLE ROXANNE GRZYBOWSKI

\author{
A Thesis Submitted in Partial \\ Fulfillment of the Requirements \\ for the Degree of \\ MASTER OF SCIENCE \\ Department of Psychology \\ ILLINOIS STATE UNIVERSITY
}

2019 
(C) 2019 Michelle Roxanne Grzybowski 


\section{GENDER-EXCLUSIVE LANGUAGE: WOMEN'S PERCEPTION \\ OF LINGUISTIC OSTRACISM, VOICE, AND \\ POWER IN POLITICS}

MICHELLE ROXANNE GRZYBOWSKI

COMMITTEE MEMBERS:

John B. Pryor, Co-Chair

Eric D. Wesselmann, Co-Chair 


\section{ACKNOWLEDGMENTS}

Foremost, I would like to express my sincere appreciation to my advisor Dr. John Pryor for the continuous support of my thesis study and research, for his patience, motivation, enthusiasm, and immense wealth of knowledge. This project would not have been possible without his many hours of dedication and guidance. A special thanks to the co-chair of my committee, Dr. Eric Wesselmann, whose direction helped me in the research and writing of this thesis.

It is with immense gratitude that I also acknowledge the support and help of my friends and colleagues, especially my dear lab sister Diana Steakley-Freeman who has inspired me in every way and with whom I spent many hours discussing and analyzing our research. I also offer my regards and good wishes to all of those who supported me in any respect during the completion of this project.

Lastly, but certainty not least, I would like to thank the woman who raised me and fostered my growth throughout every moment of my life. This thesis is lovingly dedicated to my mother, Lucyna Grzybowski. Her support, encouragement, and constant love have sustained me throughout my entire life.

M.R.G. 


\section{CONTENTS}

PCKNOWLEDGMENTS
CONTENTS
FIGURES
CHAPTER I: INTRODUCTION
\[ \begin{array}{c}\text { Stereotype Threat } \\ \text { Ostracism }\end{array} \]
Exclusive and Biased Language
Rationale

$\begin{array}{ll}\text { CHAPTER II: STUDY } 1 & 12\end{array}$

$\begin{array}{ll}\text { Method } & 12\end{array}$

$\begin{array}{ll}\text { Materials and Procedure } & 12\end{array}$

$\begin{array}{ll}\text { Results } & 14\end{array}$

$\begin{array}{ll}\text { Illinois } & 14\end{array}$

$\begin{array}{ll}\text { Wisconsin } & 15\end{array}$

$\begin{array}{ll}\text { Discussion } & 16\end{array}$

$\begin{array}{ll}\text { CHAPTER III: STUDY } 2 & 18\end{array}$

$\begin{array}{ll}\text { Method } & 20\end{array}$

$\begin{array}{ll}\text { Participants } & 20\end{array}$

$\begin{array}{ll}\text { Procedure } & 20\end{array}$

$\begin{array}{ll}\text { Measures } & 22\end{array}$

Gender-Exclusive and Gender-Neutral Language Prime 22 
Results

Analyses

Measures

Additional Findings

Discussion 


\section{FIGURES}

Figure $\quad$ Page

1. Moderated mediation conceptual model (Model 8; Hayes, 2013) depicting

how gender and feelings of empowerment predict subjective ostracism

based on the language used on the county board

26

2. Moderated mediation model assessing how gender and feelings of

empowerment predict subjective ostracism based on the language used

on the county board

28 


\section{CHAPTER I: INTRODUCTION}

In the early 1980 s, women became 50 percent of the college graduate population in the United States; today, women outnumber men in higher education with female students accounting for 55 percent of undergraduates enrolled at four-year colleges (U.S. Department of Education, 2014). Women have continued to advance, taking more entry-level jobs and entering more predominantly male-dominated fields. Despite this progress, increases in the amount of women in managerial and leadership roles have scarcely grown (Gardiner \& Tiggemann, 1999). Over the past decade, the number of women at the top of corporate America has remained stagnant, with only 21 Fortune 500 companies (4.2\%) having female CEOs (Catalyst, 2013). Women hold only $16.9 \%$ of board seats and $14.6 \%$ of Executive Officer positions, while many leadership teams and corporate boards are still all-male staffed. Likewise, at the top of the United States Government, only $18 \%$ of our elected congressional officials consist of women (CAWP, 2012). Although women outnumber men in higher education, their numbers and potential impact decline at the top of most business and organizational hierarchies. When it comes to making important decisions that affect our country and our world, women's voices are not being heard equally to those of men.

Assumptions about male authority permeate not only the relative number of women found in societal positions of power, but also the linguistic referents used to describe them. Consider the common titles of alderman, congressman, and chairman. Such titles assume that those who occupy these positions are male. The male expectation resulting from such titles could contribute to women who occupy these positions as being labeled gender role deviants (Hagan, 1990). Such a label could contribute to questioning the authority and competence of women.

Many women labeled as gender role deviants experience pushback from fellow male co-workers 
in the form of sexual harassment as well as other forms of both physical and verbal provocation (Schneider, Pryor, \& Fitzgerald, 2011). Although there has been an effort to impede and combat these explicit negative interactions in the workplace, they still exist (Collier, 1995; Schneider, Pryor, \& Fitzgerald, 2011).

\section{Stereotype Threat}

In addition to overt harassment, other, more subtle ways of excluding female coworkers have been identified. For example, sexist behavior in domains such as mathematics and engineering has been found to trigger stereotype threat in women (Schmader, 2001). Stereotype threat inhibits individuals from performing to their potential once they recognize that the possibility of failure could confirm a negative stereotype that is related to their in-group. This "threat in the air" is made up of subtle reminders in the environment that presume the ineptitude of certain groups (Steele, 1997, p. 613; Steele \& Aronson, 1995). Steele's (1997) theory of stereotype threat recognizes that in order for stereotypes to become threatening, the potential relevance of stereotypes for interpreting a stigmatized group's experiences or treatment must be made salient.

Over the years, many different factors that affect the salience of stereotypes have been documented in both laboratory and field studies. For example, in a study exploring social identity and stereotype threat, Logel, Walton, Spencer, Iserman, von Hippel and Bell (2009) reported that subtle sexist behaviors by male engineering participants (e.g., non-verbal cues of dominance such as scanning a woman's body) were sufficient to disrupt female engineering students' performance on an exam. Interacting with individuals who hold sexist stereotypes of women also results in longer-lasting effects. Specifically, female participants who were exposed to a male confederate's sexist comment while working jointly on a math task had increased stress-related 
physiological reactivity (e.g. blood pressure, heart rate, and galvanic skin response) above baseline assessments both immediately after the interaction and thirty minutes after the task had ended (Schneider, Tomaka, \& Palacios, 2001).

Similarly, workplace harassment research emphasizes the importance of organizational climate in creating conditions where gender harassment (along with other types of harassment) is more or less likely to occur; this includes management's tolerance of potentially harassing behaviors, the existence and communication of policies prohibiting harassment, and the traditional acceptance of a job as the domain of a particular gender (Schneider, Pryor, \& Fitzgerald, 2011). Therefore, managers should be aware of the negative (and non-obvious) effects of gender harassment in the workplace, such as gender-exclusive language (i.e., a type of subtly sexist language that makes reference to a single gender group thereby excluding other gender groups, including titles such as alderman and policeman; Stout \& Dasgupta, 2011).

Gendered language involves being cognizant of one's words and understanding that they can affect others either negatively or positively. Sometimes, the gendered assumptions of a position's title are evident, but other times they are not. For example, businessman or businesswoman specifies a gender, while businessperson encompasses all genders (i.e., woman, genderqueer, bigender, etc., Kuper, Nussbaum, \& Mustanski, 2012). Using gender-neutral titles such as maintenance worker, instead of maintenance man, may be an alternative to excluding certain groups of individuals. But first, a stronger link between the use of gender-exclusive language and its negative effects on the excluded group must be made. More specifically, gender-exclusive language could remind women of sexist stereotypes; in turn, heightening their anxiety about participating in group discussions, where the majority of the group consists of men. 


\section{Ostracism}

Ostracism (i.e., being excluded and ignored) is among the most powerful and ubiquitous means of social influence (Williams, 2002; also see Williams, 2007 for a review). Reactions to ostracism may differ depending on the person, time, or place, but regardless of the varying types of responses, the experience is a negative one that leads to adverse physical and psychological consequences (Cacioppo, Hawkley \& Berntson, 2003; Lynch, 1979; Williams, 2007). Across multiple studies, ostracism has been found to lower participants' mood, affect, and self-esteem (Gerber \& Wheeler, 2009) determining that no matter how it is done, or who it is done by, ostracism makes individuals feel worse (see also Nezlek, Wesselmann, Wheeler, \& Williams, 2012).

In addition to being a painful experience, ostracism threatens an individual's four fundamental needs: belonging, self-esteem, control, and meaningful existence. For example, in regard to belonging, ostracism communicates to individuals that they are not part of the social group (Baumeister \& Leary, 1995). Therefore, ostracism can be seen as a form of punishment, making the target feel as if he or she has done something wrong, in turn threatening his or her self-esteem. Similarly, ostracism also threatens an individual's sense of control over his or her interaction with the source of the experience. More specifically, there is often little that the target can do to alter a situation in which they are ostracized, leaving them helpless and unable to control the situation. Lastly, ostracism also threatens an individual's sense of meaningful existence, allowing them to experience what life would be like if they did not exist, a form of social death (Williams, 2007).

Williams $(2001 ; 2009)$ suggests that how individuals react to ostracism may depend on which of these specific needs were more threatened or which of the needs individuals are more 
motivated to fortify. For example, threats to belonging and self-esteem should encourage individuals to regain social inclusion, usually accomplished through prosocial behavior. Prosocial behavior is helpful or beneficial to someone (e.g. a group or society), and can involve cost to the self (Twenge, et al., 2007). More specifically, sharing resources with another person entails giving up one's own resources for another's benefit. This act, however, may allow for the solidification of relationships or reinclusion of an ostracized person. In contrast, threats to control and meaningful existence should provoke individuals to confirm their existence and control over others. Antisocial behavior may be used to achieve these goals through means of aggression, in order to regain a sense of control. For example, antisocial behavior, such as committing a crime or violent act, allows an individual to be acknowledged, even if for a destructive reason.

Correspondingly, studies demonstrate that reactions to ostracism are typically negative and individuals tend to react in an antisocial manner. For example, over a series of five studies, Twenge, Baumeister, DeWall, Ciarocco, and Bartels (2007) consistently found support for antisocial reactions to ostracism (i.e., individuals who were told they would live a life alone were more likely to act aggressively). Interestingly enough, it has also been found that some individuals react in a prosocial manner after being ostracized. Because humans are motivated to form and keep social bonds, and ostracism threatens this motivation, it is logical that ostracized individuals would be motivated to fulfill this need through prosocial behavior. For example, an ostracized person may make themself appear more socially attractive by helping others (Baumeister \& Leary, 1995). In a study examining ostracism and prosocial behavior, Williams, Cheung, and Choi (2000) discovered that individuals who were ostracized were more likely to conform to unanimous and incorrect judgments made in their group. The study concluded that 
ostracized individuals conformed to the group in order to strengthen their inclusionary status with the new group as a way to avoid future ostracism.

Presently, research has primarily focused on individual reactions to ostracism, and less research has been conducted on the aversive effects of ostracism based on one's group membership. Ostracism, as an interpersonal phenomenon, can also be applied to the group level in order to assess individuals' responses to ostracism based on group membership (Stout \& Dasgupta, 2011). Specifically, one such social occurrence is the use of gender-exclusive language -- the practice of using subtly exclusionary language to systematically ignore and exclude one gender group in favor of another. Few studies have explored the effects of languagebased ostracism, but research shows that the impact is negative (see Dotan-Eliaz, Sommer, \& Rubin, 2009). Consequently, the current study sought to examine the negative consequences of individuals who belong to a less advantaged gender group in reaction to gender-exclusive language.

\section{Exclusive and Biased Language}

As ostracism can manifest in a variety of forms, it is essential to recognize the versatility of its reach. One type of exclusionary behavior that is becoming more readily explored in research is related to language (see Hitlan, Kelly, Schepman, Schneider, \& Zárate, 2006 and Stout \& Dasgupta, 2011). While traditionally ostracism consists of a total absence of language (i.e. being ignored and excluded), verbal communication can also be used as an active form of exclusion. For instance, Dotan and colleagues (2004) found that speaking a foreign language in the presence of coworkers led to several negative consequences for employees working together on teams. Specifically, language exclusion resulted in decreased work efforts (for introverts) and increased aggressive behavior (for participants high in rejection sensitivity), suggesting that, for 
some, exclusive language can negatively affect group cohesion and productivity. Similarly, Hitlan, Kelly, Schepman, Schneider, and Zárate (2006) found that participants exposed to ostracism via a foreign language, reported lower levels of organizational commitment, organizational citizenship behaviors, and workgroup commitment as well as higher levels of symbolic threat and increased prejudice in comparison to included participants. Considering that interactions with foreign language speakers are becoming more common in the workplace with the increase of immigrants in the U.S. (U.S. Census Bureau, 2001), language exclusion is an important issue.

One's native language can also serve as a means to exclude others. More specifically, linguistic bias is ostensible in daily communications and is apparent through the use of pronouns that refer only to one gender, while disregarding others. Gendered language (also referred to as sexist language or unnecessarily gendered language), has been defined as "words, phrases, and expressions that unnecessarily differentiate between females and males or exclude, trivialize, or diminish [other genders]" (Parks \& Roberton, 1998, p. 455). Examples of this type of language usually include, but are not limited to, non-parallel structures (e.g., "man and wife"), lexical asymmetries (e.g., "governor" and "governess") as well as the generic use of masculine forms (e.g., "he" or "man") (Sarrasin, Gabriel, \& Gygax, 2012).

Over the years, feminist linguists have stated that language is a fundamental component in gender inequality (e.g., Lakoff, 1975). Similarly, Sherryl Kleinman (2002), a University of North Carolina sociologist, stated that male-based generics are reinforcers of "a system in which 'man' in the abstract and men in the flesh are privileged over women" (p. 300). In her essay, Why sexist language matters, Kleinman (2002) emphasizes the importance of language, stating that words are the tools of power and thought that can be used to maintain systems of oppression or to think 
in new ways; therefore, language holds the power for the possibility of a new reality. The current reality, unfortunately, cumulatively reinforces a societal message that "men are the standard" and that all others "should be subsumed by the male category" via the mechanism of our language (Kleinman, 2002, p. 300). Similarly, from history, we have learned that making a group of people invisible makes it much easier for those in power to control the members of that group. This is perhaps why linguists refer to the absence of women in male-based terminology as "symbolic annihilation" (Kleinman, 2002, p. 301).

The claims of feminist linguists and scholars about the importance of language have, in fact, been empirically supported. For example, one of the first studies conducted on the effects of gender-exclusive language (Bem \& Bem, 1973) found that women were less interested in applying for a job if the advertisements explicitly targeted men (e.g. "We need calm, coolheaded men with clear masculine voices"). Because this study was conducted over 30 years ago using blatant sexist language, a more recent study attempted to further explore this issue. In two experiments, Stout and Dasgupta (2011) had participants read a job summary for what they considered an ideal job upon graduation that contained: gender-exclusive language (he), genderinclusive language (he or she), or gender-neutral language (one). In both studies, the authors found that women reported feeling more ostracized when they were exposed to gender-exclusive language in comparison to women who read gender-inclusive and gender-neutral language. Additionally, in the gender-exclusive condition, women reported having less personal investment in the job compared to women who were exposed to the gender-inclusive or gender-neutral language conditions. In comparison to Bem and Bem's (1973) study, Stout and Dasgupta (2011) illustrated how even subtle cultural practices in our society, that do not personally ostracize all individuals, can systematically overlook entire social groups (i.e., women). 
Similarly, several studies since Bem and Bem's (1973) classic experiment have discovered that when masculine pronouns (e.g., he) as well as masculine job titles (e.g., chairman) were used to refer to both men and women, listeners' attributions about the sex, traits, and behaviors of these individuals were significantly influenced. Specifically, using these masculine referents (e.g. him) and job titles (e.g. policeman) in reference to unknown individuals made participants envision more men instead of women; by doing so, these images increased the attribution of masculine traits, which in turn resulted in participants attributing greater competence to the imagined man in comparison to when the unknown person was incongruent with their assumption (a woman) (Dayoff, 1983; McConnell \& Fazio, 1996).

Consequently, alternatives, such as police officer instead of policeman have been suggested in order to minimize the gendered assumptions of another individual. Although these alternatives have been proposed since the 1970s, and some have been accepted, gender-neutral language free of generic bias has not been fully acknowledged as the norm (e.g., Mucchi-Faina, 2005). Resistance to these gender-neutral alternatives have taken the form of a refusal to change exclusive language as well as the denial that this type of language has negative consequences or that it can be used as a tool for discrimination. Those who oppose gender-neutral language argue that it is inelegant, cumbersome, longwinded, difficult to comprehend, and ineffective (Sarrasin, Gabriel, \& Gygax, 2012). In contrast, individuals who advocate for the use of gender-neutral language view the resistance to change gendered language as a form of oppression or sexism.

\section{Rationale}

Currently, there is a lack of research investigating how subtle ostracism, such as genderexclusive language, impacts women's feelings of inclusion in an organizational setting. Genderexclusive language excludes specific gender referents (e.g., an effective chairman possesses a 
plethora of leadership experience), which makes the excluded group member feel ignored and excluded from the social situation (Stout \& Dasgupta, 2011). This subtle exclusion coincides with Williams' (2007) description of ostracism, "being ignored and excluded" (p. 429). Similarly, gender-exclusive language also occurs without explanation and may not require explicit expression of negative intent for it to have an aversive effect (Stout \& Dasgupta, 2011).

Therefore, the current research sought to add to the literature by examining how genderexclusive and gender-neutral language plays a role in women's experiences in organizational settings. In the first study, publicly available data from county board websites was used to identify and gather descriptive information on the population of interest (i.e., men and women serving as presiding officers on county boards in two Midwestern states). Additionally, proportions of women in both gender-exclusive boards and gender-neutral boards were examined in order to determine if there were differences between boards that utilized different language types (i.e., gender-exclusive and gender-neutral). A second study utilized an experimental design to further explore how the use of gender-exclusive language impacted women who were elected members of various county boards in these two Midwestern states. In study two, it was expected that:

H1: Women who were on county boards using gender-exclusive language in reference to their presiding officers (e.g., "chairman" vs. "chair" or "chairperson") would have higher feelings of subjective ostracism than women on boards who did not use this language (H1a). This relationship would be mediated by feelings of perceived disempowerment. More specifically, women who were on county boards using gender-exclusive language in reference to their presiding officers would have lower feelings of empowerment (H1b) than women on boards who do not use this language. These feelings of lower empowerment would, in turn, be related to 
feelings of increased ostracism (H1c).

H2: The impact of such gender-exclusive language upon female county board members would be moderated by gender of the board member. Therefore, women on county boards using genderexclusive language would have higher feelings of subjective ostracism, but not men.

H3: By combining the two previous models, a moderated mediation (Hayes, 2013) would occur when gender was tested as a potential moderator of the relationship between the use of genderexclusive language and feelings of empowerment (H3a), and for the relationship between the use of gender-exclusive language and perceptions of subjective ostracism (H3b), and the relationship between feelings of empowerment and subjective ostracism on the county board (H3c). 


\section{CHAPTER II: STUDY 1}

Study 1 examined whether exposure to gender-exclusive language in professional settings was correlated with differences in the proportion of women on county boards when compared to boards that did not possess such language as part of the cultural climate. Descriptive information was first gathered for each county board in order to identify whether the board utilized gender-exclusive language or gender-neutral language. It was expected that there would be significant differences between the two types of environments.

More specifically, I hypothesized that, overall, there would be more women in leadership positions on county boards that utilized gender-neutral language in comparison to boards that used gender-exclusive language. Additionally, I also expected that there would be more women in general on boards that incorporated gender-neutral language in comparison to boards that utilized gender-exclusive language. Predictions about the larger overall presence of women on county boards that use more inclusive language, as well as the higher participation of women in leadership roles on these boards, were derived from studies conducted by Stout and Dasgupta (2011); in both experiments, women reported being less interested in working at an otherwise attractive job prospect if the work climate consisted of gender-exclusive language.

\section{Method}

\section{Materials and Procedure}

The U.S. states of Illinois and Wisconsin were selected as research sites because they have similar county government organizations. For example, both states are located in the midwest and utilize the county board legislature system in comparison to other U.S. governing systems such as a board of supervisors, a county commission, or a county council. The two states also share comparable population characteristics and have a similar number of counties. 
I used the National Association of Counties (NACo) website (www.naco.org) during the span of one year in 2015, to locate all 174 county board websites (i.e., Illinois: 102; Wisconsin: 72) as well as several relevant characteristics of each board. The NACo is the principal national organization to represent county governments in the United States (About NACo -The Voice of America's Counties, 2014). The NACo researches and publishes information about counties and provides access to this information as well as a search function to locate publicly available county information. I gathered the following data from the NACo website for each county: presiding officer's name, presiding officer's gender (inferred by the individual's name, picture, use of title, and referenced pronouns in meeting minutes), language used on the board in referring to their presiding officer (e.g. titles such as chairman, chair, chairperson, etc.), total board size, number of women, county population (2013 estimate), and contact information for each board member.

The language used to address these leaders were broken down into five categories: Chairman, Chair, Chairperson, Speaker, and President. Presiding officer titles were obtained individually from each county board's website and then cross-referenced in relevant county documents (i.e., meeting minutes). Additionally, board members who held leadership positions (i.e., Economic Development Committee Chair, Finance Committee Chairman, Road and Bridge Committee Chairperson, etc.) along with their role on the county board were identified via each county board committees website, which listed the name, position title, and contact information of each committee member. 


\section{Results}

\section{Illinois}

There were a total of 1,394 active board members in the state of Illinois; 256 (18\%) of these members were women, while $1,138(82 \%)$ were men. Six of these female board members were presiding officers, in comparison to 96 who were male presiding officers. There were 86 (84\%) leaders referred to as Chairman, $12(11 \%)$ referred to as Chair, $2(2 \%)$ as Chairperson, 1 (1\%) as speaker, and $1(1 \%)$ as President. These categories can be classified as boards who used gender-exclusive language (i.e. Chairman; 86, 84\%) and boards who used gender-neutral language (i.e. Chair, Chairperson, Speaker, President; 16, 15\%).

An independent-samples t-test was conducted to compare the proportion of women in leadership positions (i.e., Economic Development Committee Chair, Finance Committee Chairman, Road and Bridge Committee Chairperson, etc.) on both gender-exclusive boards and gender-neutral county boards. Women who were presiding officers of the board (e.g., chair) were excluded from the analysis to eliminate the assumption that having a female presiding officer served as an incentive to use gender-neutral language on these boards. . There was a significant difference in the proportion of women in leadership positions (i.e., Economic Development Committee Chair, Finance Committee Chairman, Road and Bridge Committee Chairperson, etc.) on county boards that used gender-exclusive language $(M=.01, S D=.11)$ and gender-neutral language $(M=.40, S D=.51) ; t(97)=-6.37, p<.001, d=-1.06$. These results indicated that there were larger proportions of women in leadership positions on boards where gender-neutral language was used in comparison to boards where gender-exclusive language was utilized. 
Additionally, an independent-samples t-test was conducted to compare the overall proportion of women on county boards in both gender-exclusive boards and gender-neutral boards. Again, women who were presiding officers were excluded from the analysis. There was a significant difference in the proportion of women on county boards that used gender-exclusive language $(M=.11, S D=.10)$ and gender-neutral language $(M=.31, S D=.11) ; t(100)=-6.90, p$ $<.001, d=-1.77$. These results suggested that there may be a relationship between the number of women on county boards and the language being used on these boards. Specifically, the data indicated that there were larger proportions of women on boards where gender-neutral language was used in comparison to boards where gender-exclusive language was used.

\section{Wisconsin}

There were a total of 1,600 board members in the state of Wisconsin; $290(18 \%)$ of these members were women, while $1310(82 \%)$ were men. Eight of these female board members were presiding officers, in comparison to 64 who were male presiding officers. The language used to address these leaders can be broken down into three categories: Chairman, Chair, and Chairperson. There were $43(60 \%)$ leaders referred to as Chairman, $23(32 \%)$ referred to as Chair, and $6(8 \%)$ as Chairperson. These categories can be broken up into boards that used gender-exclusive language (i.e. Chairman; 43, 60\%) and boards that used gender-neutral language (i.e. Chair or Chairperson; 29, 40\%).

Similar to the state of Illinois, an independent-samples t-test was conducted to compare the proportion of women in leadership positions on both gender-exclusive boards and genderneutral county boards. Again, women who were presiding officers were excluded from the analysis. There was a significant difference in the proportion of women in leadership positions 
on county boards that use gender-exclusive language $(M=.08, S D=.27)$ and gender-neutral language $(M=.28, S D=.45) ; t(70)=-2.39, p<.001, d=-0.24$. These results indicated that there were larger proportions of women in leadership positions on boards where gender-neutral language was used in comparison to boards where gender-exclusive language was used.

Additionally, an independent-samples t-test was conducted to compare the proportion of women on county boards in both gender-exclusive and gender-neutral boards. In congruence with the previous analyses, women who were presiding officers were excluded from the analysis. There was a significant difference in the proportion of women on county boards that used gender-exclusive language $(M=.14, S D=.09)$ and gender-neutral language $(M=.23, S D=.08) ; t$ (70) $=-4.35, p<.001, d=-1.04$. The data indicated that there were larger proportions of women on boards where gender-neutral language was used in comparison to boards where genderexclusive language as used.

\section{Discussion}

The results from Study 1 yielded preliminary support for the proposed correlation between exposure to gender-exclusive language and negative impacts on women. I found that when women were in professional environments in which gender-exclusive language was used as part of the accepted cultural discourse, there were more men and fewer women on those county boards overall. Additionally, when examined if this trend translated to leadership role representation for women on boards that utilized gender-exclusive language, I found that there were significantly lower numbers of female leaders on these county boards as well; these results were even more impactful considering that women who were presiding officers of the board (e.g., chair) were excluded from the analysis. 
Although correlational in nature, these findings suggested that gender-exclusive language may play a role in women's experiences on the county boards that exclude them, possibly even hindering their ability to serve in important leadership roles that could impact the decisions made in these professional environments. Therefore, a second study sought to further explore the findings from Study 1 by determining if factors such as voice, power, feelings of control and belonging were related to the language used on these boards. 


\section{CHAPTER III: STUDY 2}

Study 1 was more descriptive in nature and was used to determine whether there were differences between boards that utilized gender-exclusive and gender-neutral language, Study 2 utilized an experimental design. First, study participants (i.e., female and male county board members) were contacted directly via their publicly available emails and invited to complete a short, voluntary survey. Second, a manipulation and counterbalancing method was introduced to Study 2 in which the order of how the questions were presented to participants varied; half of the participants received questions asking them about the way in which the presiding officer of their boards is addressed first, while the other half of participants received these questions later.

Manipulating the order of how the survey was presented to county board members served as both a counterbalancing strategy as well as a possible prime in order to make either gender-exclusive or gender-neutral language more salient. In several studies, stereotype threat has been induced in participants by priming a negative social identity that is relevant to the task. For example, in order to test the effects of automatic identity activation on math performance, Shih, Pittinsky, and Ambady (1999) primed different social identities in an initial and ostensibly unrelated questionnaire that contained priming items. Test performance was higher after priming Asian American women's Asian identity (i.e., a social identity that is positively stereotyped in math) and lower after priming their gender identity (i.e., a social identity that is negatively stereotyped in math). Similarly, another study (Steele \& Aronson, 1995) found that when asked to indicate their race on a demographics questionnaire prior to taking a test, African American participants performed worse than Caucasian participants, but performed equally to Caucasian participants when they had not been asked to identify their race. Therefore, simply priming 
someone's social identity (presumably associated with a negative stereotype) led them to feel threatened by the stereotype.

Similar to how autobiographical recall has been used to induce moods experienced during recalled events (Baker \& Guttfreund, 1993), it was expected that by making the language used on participants' county boards salient, participants would be placed into a similar state of mind during which they came into contact with this language. Thus, asking female participants how their board leaders are addressed in county boards, where gender-exclusive language is used to refer to the presiding officer, was expected to prime feelings of being ignored and excluded which, in turn should lead to a sense of disempowerment. Of course, in county boards where gender-neutral language is used to address the leaders, reminding female board members of this designation was believed to potentially result in greater feelings of inclusion and a greater sense of empowerment. Correspondingly, I expected that the familiarity of the gendered language, and in turn the priming manipulation, would not have an impact on men's' feelings of inclusion/exclusion or empowerment.

In addition to including two types of variables (i.e., manipulated and measured), the hypotheses in Study 2 were more specific than in Study 1 and sought to explore how the use of gender-exclusive language impacted women in regard to their feelings of ostracism and sense of empowerment on county boards. Specifically, I expected that women who were exposed to gender-exclusive language on their county boards would have higher overall feelings of ostracism and lower feelings of empowerment in comparison to women who were not exposed to this language on their boards. Additionally, I expected that these increased feelings of ostracism would be exacerbated (moderated) when comparing men to women and that female county board 
members exposed to gender-exclusive language would have higher feelings of ostracism than men on these same boards.

\section{Method}

\section{Participants}

Consistent with Study 1, I recruited participants via the contact information collected from the county board websites. Participants consisted of both male and female county board members from Illinois and Wisconsin. Considering that the focus of the study was on county board members' perceptions on how language is used to refer to the presiding officer of their board, county board presiding officer were excluded from survey outreach procedures. A total of 224 individuals (63 women, 161 men, 0 transgender individuals, $M$ age $=57.8$, age range: $20-66$ years) participated in the online survey. All other county board members received an email requesting participation in a study examining the perceptions of county board members. Established by the number of parameters in the hypothesized model, a G*Power (Faul, Erdfelder, Buchner \& Lang, 2009) analysis revealed that a minimum sample of 180 participants (90 men and 90 women) with an alpha at .05 and assumed power of .95 would be necessary to detect a significant difference based on the effect size $\left(\eta^{2}=.10\right)$ reported by Stout and Dasgupta (2008). This resulted in approximately 45 participants per condition and 12-13 participants per cell. Unfortunately, the desired sample sizes were not achieved due to only 63 female respondents.

\section{Procedure}

Using an Illinois State University e-mail account, the survey invitation was sent to all participants. In each e-mail, I included a brief description of the intended study along with my contact information. Individuals were incentivized to participate by being entered into a drawing to win one, $\$ 50$ Amazon gift card. If county board members were interested in participating in the study, they clicked on the provided hyperlink, which directed them to a more detailed 
description of the study, the requirements (i.e., current county board member), an informed consent form, and finally the survey. The survey was administered via Select Survey, and participants were directed to a secure webpage, which safely stored their data within the university’s firewall.

The survey consisted of a total of 19 questions, split into three sections. Section 1 of the survey served as a prime and consisted of 4 items asking about the language used on the participant's county board (i.e., How do official documents [e.g., minutes] typically refer to the presiding officer [or leader] of your board?; In board meetings, how do other members of your board typically refer to the presiding officer [or leader]?). Section 2 assessed the individual's perceptions of ostracism, voice, and power on their county board. Finally, section 3 asked for the participant's demographics.

The order of the survey varied; half of the participants received the prime first (Section 1: questions asking them about the way in which the presiding officer or leader of their boards is addressed) and the other half received these questions later, after the perceptions of ostracism, voice, and power questions. Participants were coded based upon which type of language was used to refer to the presiding officer of their board. Therefore, Section 1 served as both a counterbalancing strategy and a prime in order to make either gender-exclusive or gender-neutral language salient. Following the final part of the survey, individuals were directed to a separate screen, not linked to their survey answers, that provided them with instructions on how to be entered into the raffle. The survey took approximately 10-15 minutes to complete, and participants were told that they could contact the principal investigator with any questions or concerns related to the study. 


\section{Measures}

Gender-Exclusive and Gender-Neutral Language Prime. In order to make the language used on the county boards salient to the participants, four items were used and then randomly asked either prior to or after Section 2 of the survey. The following items were utilized to assess the language that was used on the board as well as to prime participants to think about genderexclusive or neutral language: "In board meetings, how do you typically refer to the presiding officer (or leader) of your board?", "How do official documents (e.g., minutes) typically refer to the presiding officer (or leader) of your board?" and "In board meetings, how do other members of your board typically refer to the presiding officer (or leader)?" Participants could respond to the items with one of the following answers: Chairman, Chair, Chairperson, Chairwoman, and Other. The other option provided a blank space for participants to provide their answer. Additionally, participants were asked to answer, "The presiding officer of your county board is a" with the following options: Male, Female, Other, or I don't know.

Subjective Experience of Ostracism. To measure the participant's feelings of subjective ostracism, individuals completed an adapted version of the Brief Need-Threat Scale (Williams, 2009) in order to report how satisfied their four basic needs are on their county boards. These needs include: belonging ("I felt accepted," and "I felt 'disconnected"), control ("I felt powerful," and "I felt I had control over the interaction"), self-esteem ("I felt good about myself," and "I felt liked"), and meaningful existence ("I felt invisible"' and "I felt nonexistent"). Participants were given the following instructions, "For each statement, please select the number that best represents how you felt during the last county board meeting you attended. During the last board meeting I attended..." and the items could be answered on a 5-point rating- 
scale $(1=$ Not at all; $5=$ Extremely). In addition to the previous scale, two questions were asked; these items included: "During the last county board meeting I attended I felt ignored" and "During the last county board meeting I attended I felt excluded".

Perceptions of Voice and Power. To measure the participant's feelings of voice and power, six items were generated. Individuals were asked to answer how much they agreed with the following six statements on a 5 -point rating-scale $(1=$ Strongly Disagree; $5=$ Strongly Agree): "Members on my county board value my opinions when I express them", "I have influence on my county board", "I stand my ground when I have opinions that conflict with other members of the county board", "I feel that my voice is heard in important decisions made by the county board", "Most of the other members on the county board have more influence upon important decisions made by the board than I have" (reversed scored)., and "My chances of becoming the presiding officer of my county board would be poor if I sought that position"(reversed scored).

In addition to the previously mentioned items, the following items were also asked: "The title "chairman" is an acceptable position title for any presiding officer (male or female) on my county board." and "I would prefer the use of gender neutral language, such as chair or chairperson to refer to the presiding officer, on my county board." Participants were given the following instructions, "To what extent do you agree or disagree with the following statements?" and the items could be answered on a 5 -point rating-scale $(1=$ Strongly Disagree; $5=$ Strongly Agree).

\section{Results}

\section{Analyses}

Measures. A reliability analysis was conducted on the Subjective Experience of Ostracism scale, compromising of 10 items. Cronbach's alpha revealed that the measure reached 
acceptable reliability, $\alpha=0.81$ (George $\&$ Mallery, 2003). All items were worthy of retention and used in subsequent analyses. Additionally, a reliability analysis was also conducted for the Perceptions of Voice and Power scale, which originally consisted of 5 items. Initially, Cronbach's alpha displayed an unacceptable level of reliability, $\alpha=0.61$; the analyses revealed that by removing items 3 (i.e., "I stand my ground when I have opinions that conflict with other members of the county board") and 5 (i.e., "My chances of becoming the presiding officer of my county board would be poor if I sought that position"), the alpha would increase to $\alpha=0.85$. As such, these items were removed and not utilized in the following analyses. Additionally, correlational analyses were computed between the two scales. Results suggest that the two scale correlations were also statistically significant, $r(159)=.61, p<.001$.

Threat Priming. As previously mentioned, Study 2 implemented a counterbalancing method in which the order of how survey questions were presented to participants varied. In many studies, counterbalancing is used to test for order effects and demonstrate that order had no impact upon the results. When the same effects are observed across two counterbalanced conditions, the conclusion is that order did not contribute to any observed relationships between other variables. In the current study, the counterbalancing strategy could also have served as a possible priming manipulation in which the order of when questions were presented to participants would prime them to make either gender-exclusive or gender-neutral language more salient based on the order of presentation.

More specifically, it was hypothesized that by making the language used on participants' county boards salient, county board members would be reminded of how they felt when this language was used in county board meetings. Therefore, asking female participants how their board leaders are addressed in county boards, where gender-exclusive language is used to refer 
to the presiding officer, was expected to prime feelings of being ignored and excluded. Similarly, in county boards where gender-neutral language was used to address the presiding officer, reminding female board members of this designation was believed to potentially result in greater feelings of inclusion and a greater sense of empowerment.

Upon further investigation, a nonsignificant main effect of the priming manipulation on feelings of empowerment was found $F(4,297)=.826, p=.510, d=.166$. Similarly, there was a nonsignificant main effect of the priming manipulation on subjective ostracism $F(4,297)=.167$, $p=.955, d=.041$. These null findings served as justification to use the priming variable as only a counterbalancing variable instead of also a priming variable. Thus, order was not considered in subsequent analyses.

Moderated Mediation Analysis. Women on county boards where gender-exclusive language was used to refer to the presiding officer were expected to have higher feelings of subjective ostracism than women on boards where gender-neutral language was used. Feelings of empowerment were expected to mediate this relationship. In addition, gender was expected to serve as a moderator of these relationships. This moderated mediation model can be seen depicted in Figure 1. All of these predictions were tested using the Process macro for SPSS developed by Hayes (2013).

As can be seen in Figure 2, women on gender-exclusive boards expressed lower feelings of empowerment (i.e., voice), $\mathrm{a}_{1}=.855,95 \% \mathrm{CI}=.1724$ to $1.537, p=.014$. Similarly, the gender of county board members was related to feelings of empowerment, $\mathrm{a}_{2}=.862,95 \% \mathrm{CI}=.0125$ to $1.711, p=.047$. A test of moderation of the effect of gender-exclusive language on feelings of empowerment (i.e., voice) by gender yields a significant result $\left(\mathrm{a}_{3}=-.591,95 \% \mathrm{CI}=-1.0718\right.$ to $.1092, p=.017)$. Furthermore, empowerment was positively related to subjective ostracism 


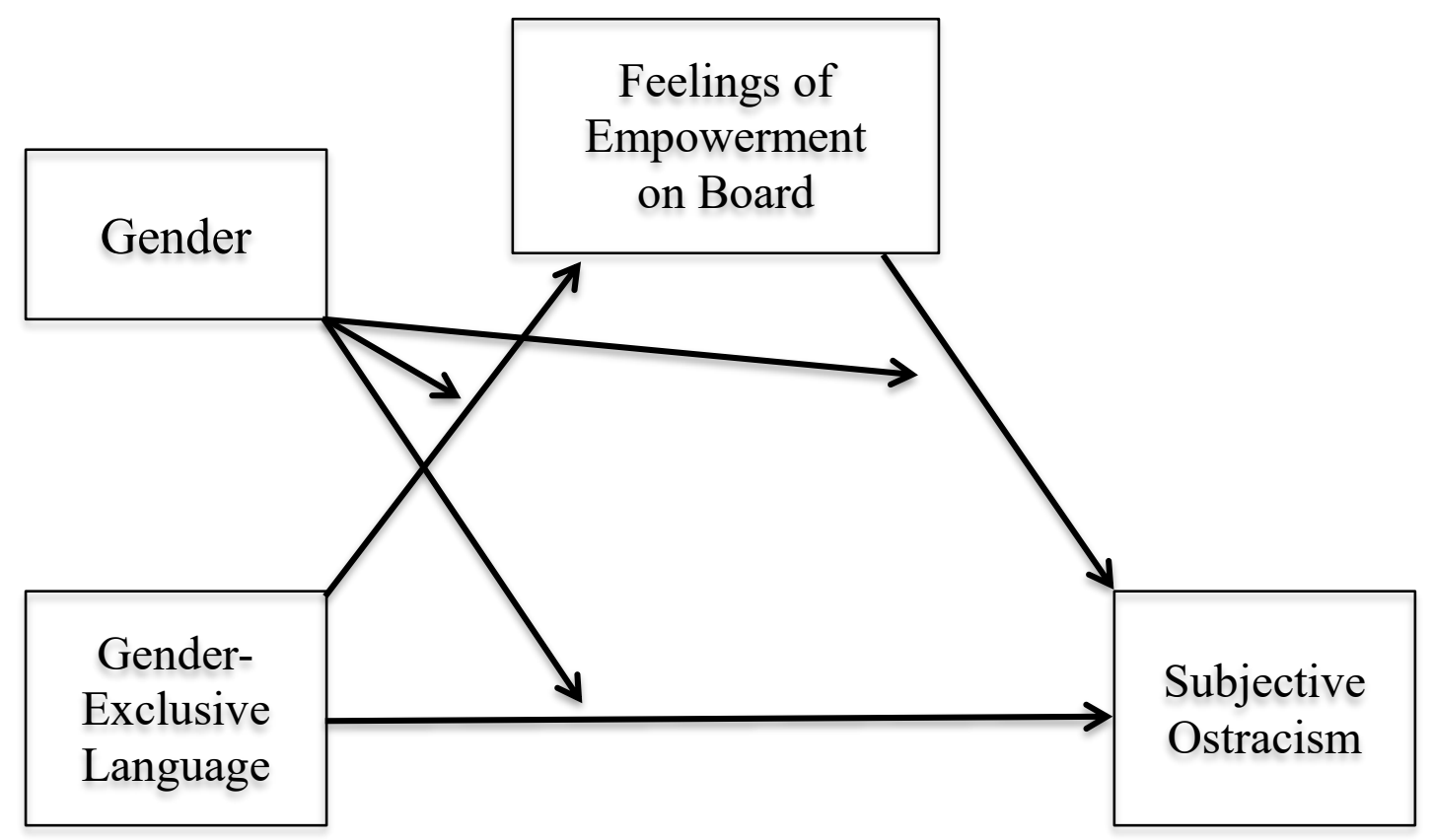

Figure 1. Moderated mediation conceptual model (Model 8; Hayes, 2013) depicting how gender and feelings of empowerment predict subjective ostracism based on the language used on the county board.

$(\mathrm{b}=-.388,95 \% \mathrm{CI}=.0557$ to $.4295, p=.016)$. As interpreted by recommendations made by Hayes (2013), a moderation mediation analysis can be inferred as this finding yielded the conclusion that the indirect effect of gender-exclusive language on subjective ostracism through the mechanism of feelings of empowerment is moderated by gender. This conclusion can be drawn because the confidence interval for the regression coefficient of the product of X (genderexclusive language) and W (gender) does not include zero; therefore, one can claim that gender is moderating the mediation of the effect of gender-exclusive language by empowerment. In this case, a 95\% bootstrap confidence interval based on 10,000 bootstrap samples does not include zero (-1.0718 to -.1092$)$.

Thus, the moderated mediation model (Hayes, 2013) proposed in hypothesis 3 was supported. Therefore, gender served as a moderator for the proposed relationship between the 
use of gender-exclusive language and feelings of empowerment (H3a) as well as for the proposed relationship between the use of gender-exclusive language and subjective ostracism (H3b), and the hypothesized relationship between feelings of empowerment and subjective ostracism (H3c). More specifically, women on county boards using gender-exclusive language in reference to their presiding officers (e.g., "chairman" vs. "chair" or “chairperson") perceived having less of a voice on their board, which in turn was related to increased feelings of subjective ostracism (i.e., feel that their basic needs are threatened) than women on boards that did not use this language.

\section{Additional Findings}

In addition to the previously mentioned findings, there are supplementary results worth noting. For example, when gender-exclusive language was used to describe the presiding leader of a county board (i.e., chairman), women expressed having lower perceptions of voice ( $M=$ 3.91, $S D=.12$ ) on these gender-exclusive boards in comparison to women who were on boards that used gender-neutral language $(M=4.32, S D=.22) ; F(1,168)=4.76, p=.03, d=-2.31$. More specifically, women on boards that utilized gender-exclusive language felt that their voices were being heard less in important decisions made by the board in comparison to women on county boards that utilized gender-neutral language.

Additionally, men were found to have higher perceptions of voice $(M=4.23, S D=.07)$ on county boards that used gender-exclusive language in comparison to women, who perceived having less of a voice on gender-exclusive county boards $(M=3.91, S D=.12) ; F(3,180)=2.73, p$ $=.05, d=3.26$. Therefore, it seems that overall, male county board members perceived that their voices were being heard more in decision making processes on boards that used genderexclusive language in comparison to women on gender-exclusive county boards. 


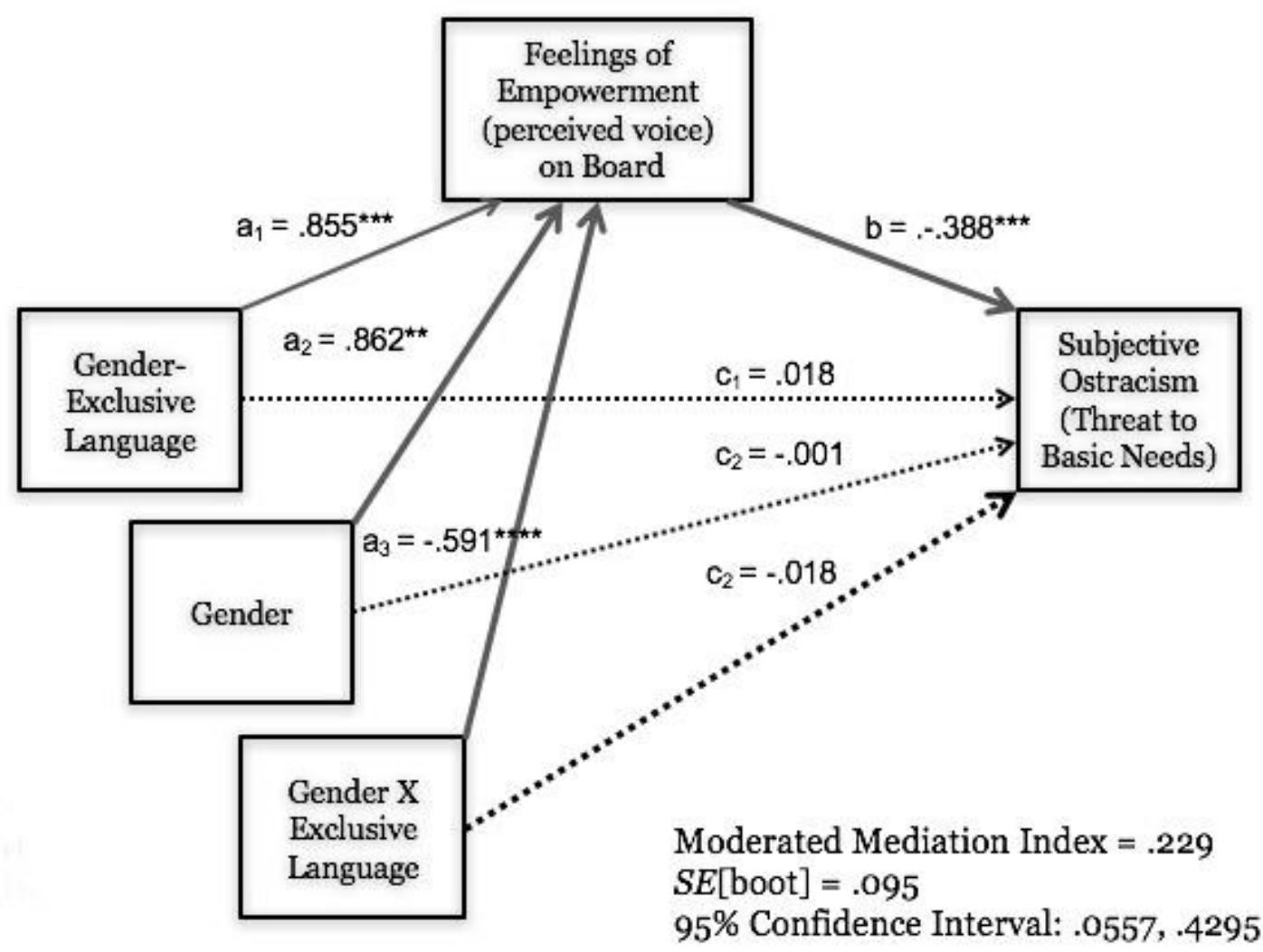

Figure 2. Moderated mediation model assessing how gender and feelings of empowerment predict subjective ostracism based on the language used on the county board.

\section{Discussion}

The results from Study 2 provided support for the link between exposure to genderexclusive language and negative impacts on women. When exposed to gender-exclusive language on their county boards, women in these environments reported having less power and feeling as if their voices were not being heard in comparison to women who were not exposed to this type of language; these perceptions were in turn related to women feeling more ostracized on boards that used gender-exclusive language.

Interestingly, the opposite trend was discovered for men; male county board members who were exposed to gender-inclusive language (gender-exclusive to women) reported higher 
perceptions of empowerment in these environments. Therefore, while male county board members perceived that their voices were being heard more in decision making processes on boards that used gender-exclusive language, women on these same boards felt lower levels of empowerment.

In sum, it appears that there is a relation between how women perceive that their voices are being heard on county boards and the language being used on those boards. Women on county boards that utilize gender-exclusive language, do not feel as included in decision making processes. In contrast, it appears that men perceive their voices being heard more on genderexclusive boards, in comparison to women on these boards. 


\section{CHAPTER IV: GENERAL DISCUSSION}

This research sought to examine how gender-exclusive and gender-neutral language play a role in women's experiences in organizational settings. More specifically, two studies surveyed how the use of gender-exclusive language was correlated to elected female members' perceptions on various county boards in two U.S. states: Illinois and Wisconsin. First, Study 1 was conducted to collect descriptive information for each county board in order to identify whether the board utilized gender-exclusive language or gender-neutral language. It was expected that there would be significant differences between the two types of environments. Specifically, I hypothesized that there would be more women in leadership positions on county boards that utilized gender-neutral language in comparison to boards that used gender-exclusive language. Additionally, I also expected that there would be more women in general on boards that incorporated gender-neutral language in comparison to boards that utilized gender-exclusive language.

The results from Study 1 largely supported these expectations. Results from both the state of Illinois and Wisconsin suggested that there may be a relationship between the number of women on county boards and the language being used on these boards. More specifically, Study 1 results indicated that there were both larger proportions of women overall as well as women in leadership positions on boards where gender-neutral language was used in comparison to boards where gender-exclusive language was used. These findings provided support for the further exploration of how gender-exclusive language may play a role in county board proceedings.

Building off of the information gathered in Study 1, Study 2 introduced a counterbalancing method where study participants were administered a short survey in which the order of how the questions were presented to participants varied. Study 2 sought to explore how the use of gender-exclusive language impacted women in regard to their perceptions of ostracism 
and empowerment on county boards. It was expected that women who were exposed to genderexclusive language on their county boards would have higher overall feelings of ostracism and lower feelings of empowerment when compared to those who were not exposed to this language on their boards. Additionally, I expected that increased feelings of ostracism would be exacerbated (moderated) when comparing men to women and that female county board members exposed to gender-exclusive language would have higher feelings of ostracism than men on these same boards.

The proposed moderated mediation model (Hayes, 2013) was found to be supported. More specifically, gender served as a moderator for the relationship between gender-exclusive language and feelings of empowerment (H3a) as well as between gender-exclusive language and subjective ostracism ( $\mathrm{H} 3 \mathrm{~b}$ ), and between feelings of empowerment and subjective ostracism $(\mathrm{H} 3 \mathrm{c})$. Therefore, women on county boards using gender-exclusive language in reference to their presiding officers (e.g., "chairman") perceived having less of a voice on their board, which in turn was related to increased feelings of subjective ostracism than women on boards that instead used gender-neutral language (e.g., "chair" or "chairperson").

Additionally, several supplementary findings were discovered. The survey results revealed that women on gender-exclusive boards expressed having lower perceptions of voice overall in comparison to women on county boards that used gender-neutral language. These results are important to consider as female county board members who serve on boards that utilize gender-exclusive language perceive that their voices are not being heard equally in important decisions made by the board.

Interestingly, men were found to have higher perceptions of voice on county boards that used gender-exclusive language in comparison to women, who perceived having less voice on 
gender-exclusive county boards. This finding is also important as it compares male county board members' perceptions on gender-exclusive boards to female county board members' perceptions on these boards. Overall, male board members perceive their voices as being heard more in decision making processes on gender-exclusive boards in comparison to women on genderexclusive boards. Therefore, women on county boards that utilize gender-exclusive language do not feel as included in decision making processes as their male counterparts.

There are many possible explanations for these relationships, but they do not negate the fact that there may be a possible connection between language use and participation in the group processes that occur on these gender-exclusive county boards. Future research should be conducted to further explore these relationships and determine their importance in county board proceedings.

\section{Strengths and Limitations}

Previous research on gender-exclusive language has examined women's reactions to hypothetical scenarios in laboratory settings. This study was the first of its kind that attempted to examine how the use of gender-exclusive language potentially influenced women's sense of participation in an actual political arena: county boards in the states of Illinois and Wisconsin. Specifically, I surveyed samples of women who are members of county boards that use either gender-exclusive or gender-neutral language in referring to the presiding officer of their board. I examined whether this naturally occurring variation was related to perceptions of ostracism as well as a sense of empowerment and voice among female county board members. In addition to surveying both men and women county board members (i.e., utilizing a comparison sample), I also employed an quasi-experimental research design and manipulated the salience of the use of gender-exclusive language by asking half of the women about how board members refer to their 
presiding officers (e.g., chairman or chair) prior to asking them about ostracism and voice. The other half of the participants were asked these same questions after the ostracism and voice questions. In several studies, stereotype threat (i.e., subtle reminders in the environment that presume the ineptitude of certain groups and inhibits individuals from performing to their potential; Steele, 1997) has been induced in participants by priming a negative social identity that is relevant to the task (e.g. Shih, Pittinsky, and Ambady, 1999; Steele \& Aronson, 1995). Therefore, asking female participants how their board leaders are addressed in their county boards, where gender-exclusive language is used to refer to the presiding officer, was expected to prime feelings of being ignored and excluded which, in turn could serve as a counter balancing measure.

Considering that this study was the first of its kind to examine the perceptions of genderexclusive language out of a laboratory setting and in the field of politics, the proposed hypotheses may have been ambitious for a study of this nature. Similarly, the required sample size predicted by the power analysis was not met due to the lower number of female respondents (i.e., there were 63 female participants and a minimum of 90 female board members was needed). Several reasons may have contributed to this lower response rate. Overall, there was a smaller population of female county board members from which to sample. More specifically, for both the state of Illinois and Wisconsin, women county board members made up $18 \%$ of the total board members in each state (i.e., There were a total of 1,394 board members in Illinois and $256(18 \%)$ of the members were women, while $1,138(82 \%)$ were men; There were a total of 1,600 board members in the state of Wisconsin and $290(18 \%)$ of the members were women, while $1310(82 \%)$ were men). Similarly, the only incentive for county board members to participate consisted of the enticement of a lottery raffle for a small monetary reward or to 
simply exercise their altruistic character. Future studies should consider sampling from an increased number of states in order to enhance participant participation as well as consider utilizing other incentive approaches. The following section offers more suggestions and considerations for future research in the area of gender-exclusive language as well as the overall field of gender-equitable language.

\section{Future Research Directions and Suggestions}

The use of he as pronoun for nouns embracing both genders is a simple, practical convention rooted in the beginnings of the English language. He has lost all suggestion of maleness in these circumstances .... It has no pejorative connotations; it is never incorrect.

(Strunk \& White, The Elements of Style, 1979, p.60)

Since the 1970s, there has been an ongoing public debate over sexist language and the negative effects it can have on women (e.g., Markowitz, 1984; Mucchi-Faina, 2005). When professor Strunk wrote his book, The Elements of Style, the advice of a renowned male scholar went largely unquestioned. Today, Strunk's view has become the minority position in the debate on gendered language, and he is no longer seen as an acceptable pronoun for all genders (Mucchi-Faina, 2005).

While many individuals and organizations admit that the pronoun he fails to function as a generic pronoun for all, the debate has continued in the realm of subtle gender-exclusive language (Stout \& Dasgupta, 2011). Currently, many organizations still utilize this subtle form of sexist language (e.g., over $80 \%$ of county boards in Illinois still use gender-exclusive language such a chairman) despite the accumulating evidence that this language has detrimental psychological effects on the women who experience it (e.g., higher feelings of social exclusion; Stout \& Dasgupta, 2011). 
Sexist bias can occur when pronouns are used carelessly, as when the masculine pronoun he is used to refer to both sexes or when the masculine or feminine pronoun is used exclusively to define roles by sex (e.g., "the nurse...she"). The use of man as a generic noun or as an ending for an occupational title (e.g., policeman instead of police officer) can be ambiguous and may imply incorrectly that all persons in the group are male. Be clear about whether you mean one sex or both sexes (APA, 2010, p. 73).

Your theories are covered in our blood. - Transsexual activist button, Toronto, mid-1990s

(Namaste, 2009, p. 27)

Additionally, feminist research on sexist language demonstrates that the effects of generic language do not solely affect women. More specifically, feminist concerns about gendered language are recognized parallel to concerns about misgendering, a form of cisgenderism (i.e., used to describe discriminatory approaches towards people's self-designated genders and body diversity; Ansara, 2010). The term cisgender can be used to describe individuals who possess the male or female reproductive organs (i.e., sex) typical of the social category of man or woman (i.e., gender) to which that individual was assigned to at birth (Aultman, 2014). Misgendering is the use of gendered language that does not equate with how individuals identify themselves (e.g., when a person who identifies as a woman is instead seen and or described as a man). Just as gender-exclusive language can be harmful to women, there have been many documented cases of the negative consequences of misgendering 'trans' individuals in medical and mental health settings (e.g., the refusal of medical treatment for a trans man who was experiencing spotting and abdominal pain because his medical record listed him as male; Ansara, 2012).

Currently, cisgenderism is used to describe discriminatory approaches towards individual's self-designated genders and body diversity (Ansara, 2010). More specifically, cisgenderism refers to the cultural and systemic ideology that denies or pathologizes gender identities that self-identify because they do not align with one's assigned gender at birth (Lennon \& Mistler, 2014). The cisgenderism ideology endorses the perspective that cisgender identities 
should be more valued than transgender identities and perpetuates a system of associated power and privilege (Lennon \& Mistler, 2014). Some of the earlier uses of cisgenderism referred to binary and essentialist categories of individuals (e.g. 'transgenderism vs. cisgenderism', 'transgender vs. cisgender', 'trans- sexual vs. cisgender') (e.g. Edelman, 2009; Serano, 2007) (Ansara \& Hegarty, 2014). Recently, psychology and feminist scholars are advocating against the use of this terminology as to "challenge the assumption that 'trans people' and 'cisgender or cissexual' people constitute distinct classes of individuals" (Ansara \& Hegarty, 2012 p. 141).

Researchers and scholars who support a cisgenderism framework make several recommendations for those seeking to incorporate a non-cisgenderist practice into their academic work and research methods. For example, scholars who follow a cisgenderism framework recommend that researchers use a self-report method to determine participants' genders, rather than asking participants to select "woman", "man", or "transgender" (since many trans individuals identify as women or men or identify as both or neither). The self-report method is also recommended in contrast to other potential methods that have been used to identify participants' genders such as attempting to use given names, visual appearance, or other misleading "clues" (Ansara \& Hegarty, 2014). Research shows that substantial errors and omissions can result from such methods (Harrison et al., 2012; Los Angeles County Department of Public Health, 2012, see Ansara and Hegarty, 2013). More specifically, researchers can provide their participants with a blank text box in which participants can respond to the question, "How do you currently describe your gender?"

Similarly, in regard to researcher's writing, Ansara and Hegarty (2014), also recommended that researchers avoid using "female" and "male" interchangeably with "woman" and "man" as doing so promotes misgendering. Ansara and Hegarty (2014) explain that 
degendering language serves to delegitimize individual's own current descriptions of their genders by focusing on their presumed past or current biological descriptions (e.g., "female-tomale transsexual" or "biological female"). Correspondingly, phrases such as "female-to-male transgender person" or "female-to-male transsexual" use objectifying biological language that can actually construct some men as a suspect linguistic category of degendered "persons" and not "men". In contrast to this exclusionary approach, researchers might instead consider using the pronouns he, him, or his in reference to a self-identified man, unless otherwise directed by that individual.

In the Guidelines for Non-Sexist Language (APA, 1977), which appeared in a recent American Psychological Association (APA) Publication Manual (APA, 2010), the APA cautioned its readers against using generic masculine language (e.g., using "he" and "man" to refer to people in general rather than specifically to men). Correspondingly, APA guidelines also recommend their readers to "refer to a transgender person using words (proper nouns, pronouns, etc.) appropriate to the person's gender identity or gender expression, regardless of birth sex" and to "use the pronouns he, him, or his in reference to a female-to-male transgender person" (2010, p. 74).

Considering that many theorists have argued that misgendering negatively affects gender independent individuals (e.g., Ansara, 2010, 2012; Serano, 2007; Winters, 2008) and that recent empirical research documents the negative consequences of misgendering in medical settings (e.g., Craig, 2005; Dewey, 2008) as well as the negative impacts of the masculine generic language (e.g., Stout \& Dasgupta, 2011), the recommendations made by the APA seem beneficial. However, it is important to take notice of the APA's use of the phrases "both sexes" and "the other sex" to refer to gender (p. 73). By conflating the terms "sex" and "gender" in such 
a contemporary context, the use of "both sexes" endorses the erasure of genderfluid as well as intersex individuals, whose bodies reveal the inadequacy of making the assumption that "female" and "male" bodies cannot co-exist in the same body (Ansara \& Hegarty, 2014).

Correspondingly, APA further hinders efforts to reduce bias in language via the conflation of "man" and "male". Unfortunately, assigning gender in a way that fails to match individual's own understanding of their own gender is a common methodological procedure in research. For example, this can be observed when researchers do not inquire about participants' own descriptions of their genders. Researchers who ask their participants to select either "woman" or "man" or "transgender" as their gender overlook that many transgender individuals identify as simply woman or man, as well as that many individuals identify as both or neither. The APA Publication Manual (2010) constructs gender as being entirely binary. Subsequently, it makes no reference to non-binary gender pronouns such as "ze" as well as other individuals' preferences to be referred to as "they" or to use their given name in place of pronouns (Ansara \& Hegarty, 2014). This is important to note considering that researchers who follow the publication and writing guidelines outlined by APA are likely to misgender participants whose genders are not binary.

It is also important to note, that almost all of the research conducted on misgendering directly concerns the misgendering of women by the use of masculine generics (e.g., research on gender-exclusive language) (Ansara \& Hegarty, 2013). Similarly, The Publication Manual (APA, 2010) advises its readers to avoid the use of masculine generics such as "he" and "man" to refer to individuals in general, rather than specifically to men considering that such generics "may imply incorrectly that all persons in the group are male" (p. 73). Unfortunately, this statement only indicates concern about the effects of misgendering on women. 
Therefore, both psychological and feminist research on sexist or gendered language may potentially benefit by exploring recent research on misgendering in order to surpass the incorrect assumptions that solely women are affected by the adverse effects of generic language. More specifically, future research in this area should consider that "women", as a group, has very distinct boundaries and that researchers can instead determine individual's genders more accurately and reliably. For example, a cisgenderism framework (Ansara, 2010, 2012; Ansara and Hegarty, 2012, 2013) could potentially benefit both feminist and psychological research methodologies as well as by reducing discriminatory gender ideology in publications.

Therefore, although the gendered language debate has been present for decades, today, it takes on a distinctive form in comparison to past arguments (e.g., gender-exclusive language and misgendering). While this study specifically focused on the adverse effects of gender-exclusive language on women, future research should work to include individuals whose genders are not binary (e.g., genderqueer, bigender, etc.). While these efforts are being made by individual researchers (see Ansara \& Hegarty, 2012; 2013; 2014), changes are not being as equally and increasingly implemented at a systematic level via policy change initiatives (for gender-equitable policy change initiatives see Sweden's national implementation effort of han; Sendén, Bäck, \& Lindqvist, 2015).

Although gendered language bias has historically oppressed women and individuals whose genders are not binary, there are also many examples of resistance to gender-inequitable language (e.g., various U.S. academic institutions have begun to adjust campus protocols to include students and staff who possess a gender fluid identity; see Howard, 2015). These acts of resistance are important because they bring the issue of gender-equitable language to the forefront. In order to move forward, the realm in which policy initiatives such as these are being 
made must be gender-equitable in of itself. Here, researchers can participate in the resistance movement and change of gender-inequitable language by further conducting research on and making others aware of these issues as well as using gender-equitable language themselves. 


\section{REFERENCES}

Baker, R. C., \& Guttfreund, D. G. (1993). The effects of written autobiographical recollection induction procedures on mood. Journal of Clinical Psychology, 49, $563-568$

Baumeister, R.F., \& Leary, M.R. (1995). Anxiety and social exclusion. Journal of Social and Clinical Psychology, 9, 165-195.

Baumeister, R. F., \& Leary, M. R. (1995). The need to belong: Desire for interpersonal attachments as a fundamental human motivation. Psychological Bulletin, 117, 497-529.

Bem, S. L., \& Bem, D. B. (1973). Does sex-biased job advertising “aid and abet" sex discrimination? Journal of Applied Social Psychology, 3, 6-18.

Catalyst, 2013 First Step: Gender Diversity at the Top Pays Off From the Boardroom to the C-Suite, http://www.catalyst.org/knowledge/first-step-gender-diversitytop-pays-boardroom-c-suite

Catalyst, 2013 Catalyst Census: Fortune 500 Women Executive Officers and Top Earners (December 2013)", http://www.catalyst.org/knowledge/2013-catalystcensus-fortune-500-women-board-directors

Center for American Women and Politics (CAWP), 2012, Record Number of Women Will Serve in Congress, http://www.cawp.rutgers.edu/press_room/news/ documents/ PressRelease_11-07-12.pdf

Crocker, J., \& Major, B. (1989). Social stigma and self-esteem: The self-protective properties of stigma. Psychological Review, 96, 608. 
Dayhoff, S. A. (1983). Sexist language and person perception: Evaluation of candidates from newspaper articles. Sex Roles, 9, 527-539.

Dion, K. L., \& Earn, B. M. (1975). The phenomenology of being a target of prejudice. Journal of Personality and Social Psychology, 32, 944-950.

Dotan-Eliaz, O., Sommer, K. L., \& Rubin, Y. S. (2009). Multilingual groups: Effects of linguistic ostracism on felt rejection and anger, coworker attraction, perceived team potency, and creative performance. Basic and Applied Social Psychology, 31, 363-375.

Dotan, O., Rubin, Y., \& Sommer, K.L. (April, 2004). Impact of language diversity on teammembers' self-feelings, team-perceptions, and individual-performance. Presented at the annual conference of the Society for Industrial and Organizational Psychology, Chicago, IL.

Faul, F., Erdfelder, E., Buchner, A., \& Lang, A. G. (2009). Statistical power analyses using G* Power 3.1: Tests for correlation and regression analyses. Behavior Research Methods, 41, 1149-1160.

Gastil, J. (1990). Generic pronouns and sexist language: The oxymoronic character of masculine generics. Sex Roles, 23, 629-643.

Gardiner, M., \& Tiggemann, M. (1999). Gender differences in leadership style, job stress and mental health in male-and female-dominated industries. Journal of Occupational and Organizational Psychology, 72, 301-315.

Gardner, W. L., Pickett, C. L., \& Brewer, M. B. (2000). Social exclusion and selective memory: How the need to belong influences memory for social events. Personality and Social Psychology Bulletin, 26, 486-496. 
Gerber, J., \& Wheeler, L. (2009). On being rejected: A meta-analysis of experimental research on rejection. Perspectives on Psychological Science, 4, 468-488.

Hayes, A. F. (2013). Introduction to Mediation, Moderation, and Conditional Process Analysis. NY: Guilford.

Hayes, A. F., Matthes, J., \& Eveland, W. P. Stimulating the quasistatistical organ: Fear of social isolation motivates the quest for knowledge of the opinion climate. Manuscript submitted for publication.

Hamilton, M. C. (1988). Using masculine generics: Does generic He increase male bias in the user's imagery? Sex Roles, 19, 785-799.

Hitlan, R. T., Kelly, K. M., Schepman, S., Schneider, K. T., \& Zárate, M. A. (2006). Language exclusion and the consequences of perceived ostracism in the workplace. Group Dynamics: Theory, Research, and Practice, 10, 56.

Hyde, J.S. (1984). Children's understanding of sexist language. Developmental Psychology, 20, 697-706.

Kena, G., Aud, S., Johnson, F., Wang, X., Zhang, J., Rathbun, A., \& Kristapovich, P. (2014). The condition of education 2014. Washington, DC: US Department of Education.

Liben, L. S., Bigler, R. S., \& Krogh, H. R. (2002). Language at work: Children's gendered interpretations of occupational titles. Child Development, 73, 810-828.

Logel, C., Walton, G. M., Spencer, S. J., Iserman, E. C., von Hippel, W., \& Bell, A. E. (2009). Interacting with sexist men triggers social identity threat among female engineers. Journal of Personality and Social Psychology, 96, 1089-1103. 
Luhtanen, R., \& Crocker, J. (1992). A collective self-esteem scale: Self-evaluation of one's social identity. Personality and Social Psychology Bulletin, 18, 302-318.

McConnell, A. R., \& Fazio, R. H. (1996). Women as men and people: Effects of gender-marked language. Personality and Social Psychology Bulletin, 22, 1004-1013.

Miller, M. M., \& James, L. E. (2009). Is the generic pronoun he still comprehended as excluding women? The American Journal of Psychology, 483-496.

Morrison, K. R., \& Matthes, J. (2011). Socially motivated projection: Need to belong increases perceived opinion consensus on important issues. European Journal of Social Psychology, 41, 707-719.

Moulton, J., Robinson, G. M., \& Elias, C. (1978). Sex bias in language use: "Neutral” pronouns that aren't. American Psychologist, 33, 1032-1036.

National Association of Counties. (2014). About NACo -The Voice of America's Counties. In National Association of Counties (NACo). Retrieved March 9, 2015, from http://www.naco.org/about/Pages/default.aspx.

Schmitt, M. T., Branscombe, N. R., \& Postmes, T. (2000). The pervasiveness of prejudice against the ingroup and its consequences for psychological well-being. Manuscript in progress, University of Kansas.

Schmitt, M. T., Branscombe, N. R., \& Kobrynowicz, D., Owen, S. Perceiving Discrimination Against One's Gender Group has Different Implications for Well-Being in Women and Men. Manuscript submitted for publication.

Schneider, J. W., \& Hacker, S. L. (1973). Sex role imagery and use of the generic "man" in introductory texts: A case in the sociology of sociology. The American Sociologist, 8, 1218. 
Schneider, K.T., Pryor, J. B., \& Fitzgerald, L. F. (2011). Sexual harassment research in the United States. In S. Einarsen, H. Hoel, D. Zapf, \& C. Cooper (Eds.), Workplace bullying: Development in theory, research and practice (pp. 245-266). London, UK: CRC Press.

Schneider, K. T., Tomaka, J., \& Palacios, R. (2001). Women's cognitive, affective, and physiological reactions to a male coworker's sexist behavior. Journal of Applied Social Psychology, 31, 1995- 2018.

Shih, M., Pittinsky, T. L., \& Ambady, N. (1999). Stereotype susceptibility: Identity salience and shifts in quantitative performance. Psychological Science, 10, 80-83.

Steele, C. M., \& Aronson, J. (1995). Stereotype threat and the intellectual test performance of African Americans. Journal of Personality and Social Psychology, 69, 797-811.

Steele, C. M. (1997). A threat in the air: how stereotypes shape intellectual identity and performance. American Psychologist, 52, 613.

Stout, J. G., \& Dasgupta, N. (2011). When he doesn't mean you: Gender-exclusive language as ostracism. Personality and Social Psychology Bulletin, 37, 757-769.

Thompson, H. L., \& Richardson, D. R. (1983). The Rooster Effect Same-Sex Rivalry and Inequity as Factors in Retaliative Aggression. Personality and Social Psychology Bulletin, 9, 415-425.

Twenge, J. M., Baumeister, R. F., DeWall, C. N., Ciarocco, N. J., \& Bartels, J. M. (2007). Social exclusion decreases prosocial behavior. Journal of Personality and Social Psychology, 92, 56.

Williams, K. D. (2002). Ostracism: The power of silence. Guilford Press. 
Williams, K. D. (2007). Ostracism: The kiss of social death. Social and Personality Psychology Compass, 1, 236-247.

Williams, K. D. (2009). Ostracism: Effects of being excluded and ignored. In M. P.

Wirth, J. H., \& Williams, K. D. (2009). They don't like our kind': Consequences of being ostracized while possessing a group membership. Group Processes \& Intergroup Relations, 12, 111-127.

Zadro, L., Williams, K. D., \& Richardson, R. (2004). How low can you go? Ostracism by a computer is sufficient to lower self-reported levels of belonging, control, selfesteem, and meaningful existence. Journal of Experimental Social Psychology, 40, 560-567.

Zanna (Ed.), Advances in Experimental Social Psychology (Vol. 41, pp. 275-314). New York: Academic Press. 
Part 1

\section{APPENDIX A: SURVEY QUESTIONAIRE}

In board meetings, how do other members of your board typically refer to the presiding officer (or leader)?

Chairman Chair Chairperson Chairwoman Other

In board meetings, how do you typically refer to the presiding officer (or leader) of your board?

Chairman Chair Chairperson Chairwoman Other

How do official documents (e.g., minutes) typically refer to the presiding officer (or leader) of your board?

Chairman Chair Chairperson Chairwoman Other

The presiding officer (or leader) of your board is

Male Female Transgender I don't know

$\underline{\text { Part } 2}$

For each statement, please select the number that best represents how you felt during the last county board meeting you attended:

During the last county board meeting I attended...

I felt liked.

$\begin{array}{lllllll}\text { Not at all } & 1 & 2 & 3 & 4 & 5 & \text { Extremely }\end{array}$

I felt I had control over the interaction.

$\begin{array}{lllllll}\text { Not at all } & 1 & 2 & 3 & 4 & 5 & \text { Extremely }\end{array}$

I felt invisible.

$\begin{array}{lllllll}\text { Not at all } & 1 & 2 & 3 & 4 & 5 & \text { Extremely }\end{array}$

I felt powerful.

$\begin{array}{lllllll}\text { Not at all } & 1 & 2 & 3 & 4 & 5 & \text { Extremely }\end{array}$

I felt accepted.

$\begin{array}{lllllll}\text { Not at all } & 1 & 2 & 3 & 4 & 5 & \text { Extremely }\end{array}$

I felt "disconnected".

Not at all $11 \quad 2 \quad 3 \quad 4 \quad 5 \quad$ Extremely

I felt good about myself.

$\begin{array}{lllllll}\text { Not at all } & 1 & 2 & 3 & 4 & 5 & \text { Extremely }\end{array}$

I felt non-existent.

$\begin{array}{lllllll}\text { Not at all } & 1 & 2 & 3 & 4 & 5 & \text { Extremely }\end{array}$

I felt ignored.

$\begin{array}{lllllll}\text { Not at all } & 1 & 2 & 3 & 4 & 5 & \text { Extremely }\end{array}$

I felt excluded.

$\begin{array}{lllllll}\text { Not at all } & 1 & 2 & 3 & 4 & 5 & \text { Extremely }\end{array}$

To what extent do you agree or disagree with the following statements?

Members on my county board value my opinions when I express them.

(1) Strongly Agree (2) Agree (3) Neutral (4) Disagree (5) Strongly Disagree

I have influence on my county board's decisions.

(1) Strongly Agree (2) Agree (3) Neutral (4) Disagree (5) Strongly Disagree 
I stand my ground when I have opinions that conflict with other members of the county board.

(1) Strongly Agree (2) Agree (3) Neutral (4) Disagree (5) Strongly Disagree

I feel that my voice is heard in important decisions made by the county board.

(1) Strongly Agree (2) Agree (3) Neutral (4) Disagree (5) Strongly Disagree

My chances of becoming the presiding officer of my county board would be poor if I sought that position.

(1) Strongly Agree (2) Agree (3) Neutral (4) Disagree (5) Strongly Disagree

$\underline{\text { Part } 3}$

Demographics

Please specify your age: years old

Please specify your Gender:

Male___ Female___ Transgender___ Prefer not to

Describe your race or ethnic background.

Alaskan Native

American Indian

Black/African

Chinese

Japanese

Korean

Other Asian

Pacific Islander

Hispanic/Latino

White/Non-Hispanic

Middle Eastern

East Indian

Australian Aboriginie

To what extent do you agree or disagree with the following statements?

I consider myself a feminist.

(1) Strongly Agree (2) Agree (3) Neutral (4) Disagree (5) Strongly Disagree

The title "chairman" is an acceptable position title for any presiding officer (male or female) on my county board.

(1) Strongly Agree (2) Agree (3) Neutral (4) Disagree (5) Strongly Disagree

I would prefer the use of gender-neutral language, such as chair or chairperson, on my county board.

(1) Strongly Agree (2) Agree (3) Neutral (4) Disagree (5) Strongly Disagree

How many men are on your county board?

How many women are on your county board?

How many transgender persons are on your county board? 